\title{
PENGARUH KOMPETENSI DAN BUDAYA ORGANISASI PADA KINERJA PENYUSUN LAPORAN KEUANGAN SATUAN KERJA MELALUI KOMITMEN ORGANISASI
}

\author{
Veriyanto Adi Prakoso ${ }^{1}$ \\ Ni Made Dwi Ratnadi ${ }^{2}$ \\ IGAM Asri Dwija Putri ${ }^{3}$ \\ ${ }^{1,2,3}$ Fakultas Ekonomi dan Bisnis Universitas Udayana (Unud), Bali, Indonesia \\ E-mail : veri.adi9@gmail.com
}

\begin{abstract}
ABSTRAK
Tujuan penelitian ini untuk membuktikan secara empiris pengaruh kompetensi dan budaya organisasi pada kinerja penyusun laporan keuangan satuan kerja kementerian/lembaga dengan komitmen organisasi sebagai variabel intervening. Penelitian ini dilaksanakan pada satuan kerja kementerian/lembaga di wilayah pembayaran KPPN Denpasar. Sampel yang digunakan yaitu sebanyak 144 responden dengan teknik purposive sampling. Pengumpulan data dilakukan menggunakan kuesioner. Teknik analisis data menggunakan Path Analysis. Hasil penelitian ini menunjukkan bahwa kompetensi berpengaruh positif pada kinerja penyusun laporan keuangan, budaya organisasi berpengaruh positif pada kinerja penyusun laporan keuangan, komitmen organisasi berpengaruh positif pada kinerja penyusun laporan keuangan, kompetensi berpengaruh positif pada komitmen organisasi penyusun laporan keuangan, budaya organisasi tidak berpengaruh pada komitmen organisasi penyusun laporan keuangan, kompetensi berpengaruh positif pada kinerja penyusun laporan keuangan melalui komitmen organisasi dan budaya organisasi berpengaruh positif pada kinerja penyusun laporan keuangan melalui komitmen organisasi.
\end{abstract}

Kata kunci: kompetensi, budaya organisasi, komitmen organisasi, kinerja

\begin{abstract}
This study aims to obtain empirical evidence of the influence of competence, organizational culture on performance of the financial report's authors work unit ministry/institutions through organizational commitment. The research was conducted at the working unit ministries / agencies in the area of payment KPPN Denpasar. Samples used as many as 144 respondents using purposive sampling technique. Data is collected using a questionnaire. Data were analyzed using Path Analysis. The results of this study indicate that competence of a positive effect on the performance of financial report's authors, organizational culture of positive effect on performance financial report's authors, organizational commitment of a positive effect on the performance of financial report's authors, competency of positive effect on organizational commitment of financial report's authors, organizational culture had no effect on organizational commitment of financial report's authors, competence of positive effect on the performance of the financial report's authors through organizational commitment and organizational culture of positive effect on the performance of the financial report's authors through organizational commitment.
\end{abstract}

Keywords: competence, organizational culture, organizational commitment, performance 


\section{PENDAHULUAN}

Laporan keuangan instansi pemerintah merupakan bentuk pertanggungjawaban manajemen atas penggunaan sumber daya yang dikelola melalui mekanisme APBN/APBD sebagai wujud akuntabilitas dan transparansi. Semakin menguatnya tuntutan masyarakat terhadap pelaksanaan akuntabilitas publik menimbulkan dampak bagi manajemen institusi pemerintah untuk membuka diri kepada masyarakat untuk memberikan informasi terkait penyelenggaraan pemerintahan salah satunya laporan keuangan. Penyusunan laporan keuangan merupakan suatu kebutuhan transparansi yang merupakan syarat pendukung adanya akuntabilitas berupa keterbukaan pemerintah atas aktivitas pengelolaan sumber daya publik.

Laporan Keuangan Kementerian/Lembaga (LKKL) dipengaruhi oleh penyusunan laporan keuangan unit akuntansi di bawahnya karena prinsip penggabungan yang dilakukan secara berjenjang. Anggraheni (2010) adapun kelemahan dari sistem berjenjang ini adalah adanya akumulasi kesalahan dari pada level terbawah. Akan tetapi, tahun 2016 pelaksanaan rekonsiliasi telah menggunakan aplikasi e-rekon yaitu aplikasi berbasis web yang dikembangkan dalam rangka proses rekonsiliasi data transaksi keuangan dan penyusunan laporan keuangan kementerian/lembaga. Pelaksanaan rekonsiliasi dilakukan hanya pada satuan kerja tingkat Unit Akuntansi Kuasa Pengguna Anggaran (UAKPA), sehingga terbentuk single database yang berisi data satuan kerja seluruh kementerian/lembaga sebagai bahan penyusunan laporan keuangan (https://portalkppn.com). 
Rekonsiliasi merupakan hal penting dalam penyusunan laporan keuangan yang akuntabel dan kredibel, karena dapat mengurangi terjadinya perbedaan pencatatan transaksi keuangan. Dalam pelaksanaan rekonsiliasi masih ditemukan beberapa satuan kerja yang belum atau terlambat melaksanakan rekonsiliasi, kesalahan pegawai dalam menginput data ke sistem sehingga data tidak valid dan kurangnya kemampuan pegawai dalam memahami peraturan tentang perbendaharaan (www.kppntanjungbalai.com).

Kinerja penyusun laporan keuangan tercermin dalam outputnya yaitu laporan keuangan dan outcomenya yaitu kualitas laporan keuangan. Laporan Keuangan Pemerintah Pusat (LKPP) memperoleh predikat Wajar Dengan Pengecaualian (WDP) dalam enam tahun terakhir dari tahun 2009 sampai 2015. Capaian opini laporan keuangan kementerian lembaga (LKKL) masih di bawah target Rencana Pembangunan Jangka Menengah (RPJMN) 2010-2014 yang menetapkan target opini Wajar Tanpa Pengecualian sebanyak 81 Kementerian/Lembaga pada tahun 2014 (BPK RI, 2015).

Implementasi akuntansi pemerintah berbasis akrual yang telah dilaksanakan masih terdapat permasalahan yaitu pemahaman penyusun laporan keuangan atas akuntansi berbasis akrual yang terbatas, penggunaan aplikasi yang baru dan rekonsiliasi data sistem akuntansi instansi ( $\underline{\text { Http:djpbn.kemenkeu.go.id). }}$ Peningkatan kompetensi pegawai menjadi hal mutlak yang harus dilaksanakan melalui pendidikan dan pelatihan serta bimbingan teknis tentang akuntansi berbasis akrual karena terbatasnya SDM dengan pengetahuan akuntansi dan kemampuan SDM dalam pengelolaan asset merupakan permasalahan dalam 
penerapan akuntansi pemerintah berbasis akrual (Mimba, 2013). Herawati (2015) menyebutkan bahwa kompetensi berpengaruh terhadap kinerja. Orang yang memiliki kompetensi tinggi diharapkan memiliki kinerja yang baik sehingga setiap pegawai dituntut untuk meningkatkan kompetensinya dalam usaha peningkatan kinerja organisasi.

Suatu organisasi diperlukan adanya budaya organisasi yang kuat agar nilainilai yang ada dapat benar-benar dipahami dan diterapkan secara mendalam, dianut dan diperjuangkan oleh para pegawai agar dapat tercapai kinerja yang baik dan optimal. Hakim (2015) menyatakan bahwa budaya organisasi memiliki hubungan linier dengan kinerja, sehingga semakin baik budaya organisasi akan diikuti dengan peningkatan kinerja karyawan.

Banyak penelitian terdahulu mengenai pengaruh kompetensi dan budaya organisasi pada kinerja pegawai, hasilnya terdapat ketidakkonsistenan. Untuk mengatasi inkonsisten hasil-hasil penelitian tersebut diperlukan pendekatan kontinjensi (Govindarajan, 1986 dalam Hustanarina dan Nor, 2007) yaitu dengan cara memasukan variabel lain yang mungkin mempengaruhi hubungan kompetensi dan budaya organisasi dengan kinerja. Variabel yang diperkirakan dapat mempengaruhi hubungan kompetensi dan budaya organisasi dengan kinerja tersebut adalah komitmen organisasi. Komitmen organisasi merupakan suatu keadaaan di mana seorang karyawan memihak organisasi serta tujuan dan fungsinya dan keinginannya untuk mempertahankan keanggotaan dalam organisasi tersebut (Robbins dan Judge, 2008:100). 
Rumasukun et al. (2015) menyatakan komitmen organisasi merupakan variabel mediasi pengaruh kompetensi pegawai terhadap kinerja, kompetensi pegawai kuat akan berpengaruh terhadap komitmen organisasi yang lebih tinggi, dan komitmen organisasi yang lebih tinggi dapat meningkatkan kinerja pegawai. Patulak et al. (2013) menyimpulkan bahwa budaya organisasi merupakan bagian dari kelangsungan organisasi yang terbentuk dari sikap dan perilaku anggota organisasi, budaya dapat membentuk komitmen anggotanya. Anggota organisasi yang mempunyai komitmen yang kuat akan bekerja dengan dedikasi sehingga menghasilkan kinerja yang baik.

Tujuan dari penelitian ini adalah untuk memperoleh bukti empiris pengaruh kompetensi pada kinerja, pengaruh budaya organisasi pada kinerja, pengaruh komitmen organisasi pada kinerja, pengaruh kompetensi pada komitmen organisasi, pengaruh budaya organisasi pada komitmen organisasi, pengaruh kompetensi pada kinerja melalui komitmen organisasi dan pengaruh budaya organisasi pada kinerja melalui komitmen organisasi. Hasil penelitian ini diharapkan dapat memberi manfaat yaitu tambahan kontribusi informasi, referensi dan masukan bagi satuan kerja/instansi pemerintah dalam menerapkan pengembangan sumber daya manusia. Selain itu, penelitian memberikan kontribusi pada pengembangan goal setting theory sehingga dapat berguna bagi penelitian selanjutnya.

Goal Setting Theory dikemukakan oleh Locke (1968). Goal Setting Theory atau teori penetapan tujuan tidak hanya mempengaruhi kerja itu sendiri, tetapi dapat juga mendorong pegawai untuk mencoba menemukan metode yang 
lebih baik untuk melakukan pekerjaan. Teori penetapan tujuan berdasarkan pada intuitif yang solid. Teori penetapan tujuan menyatakan bahwa tujuan yang cukup sulit ternyata menghasilkan tingkat kinerja yang lebih tinggi daripada tujuan yang lebih mudah dan dapat menghasilkan tingkat output yang tinggi.

Adiputri (2014) menyatakan bahwa pendidikan yang tinggi belum tentu menentukan tingginya kompetensi seseorang, kompetensi didapatkan dengan pelatihan-pelatihan secara rutin. Kurangnya pelatihan yang diperoleh akan membuat pegawai kurang yakin dalam melakukan tugas dan fungsinya sehingga dapat mempengaruhi kinerjanya. Pegawai yang telah mendapatkan pelatihan akan memiliki kompetensi sehingga mampu meningkatkan kinerjanya. Hasil penelitian tersebut selaras dengan Herawati (2015) dan Haryanti dan Cholil (2015) bahwa variabel kompetensi berpengaruh signifikan terhadap kinerja.

$\mathrm{H}_{1}$ : Kompetensi berpengaruh positif pada kinerja penyusun laporan keuangan satuan kerja wilayah pembayaran KPPN Denpasar.

Budaya yang kuat akan memperkokoh sumber daya manusia yang ada dalam suatu organisasi dan akan meningkatkan kinerja karyawan (Rivai dan Basri, 2005). Uddin (2013) dan Hakim (2015) menyatakan budaya organisasi dapat digunakan sebagai alat manajemen untuk mencapai efisiensi, efektivitas, produktivitas, etos kerja dan dapat mempengaruhi sikap dan perilaku karyawan dalam upaya untuk mencapai tujuan organisasi. Organisasi yang memiliki budaya yang kuat akan mampu meningkatkan kinerja karyawan, menumbuhkan semangat kebersamaan dikalangan para anggotanya, meningkatkan rasa nyaman dan loyal terhadap organisasi serta mampu meningkatkan kinerja organisasi. 
$\mathrm{H}_{2}$ : Budaya organisasi berpengaruh positif pada penyusun laporan keuangan satuan kerja wilayah pembayaran KPPN Denpasar.

Hakim (2015) menunjukkan bahwa untuk meningkatkan kinerja organisasi, khususnya yang berkaitan dengan kualitas, kuantitas, ketepatan waktu dan efektivitas biaya, perlu untuk pengawasan dan berdampak sangat besar antar sehingga diperlukan dukungan dari komitmen karyawan. Samad (2011), Cohen (1999), Tolentino (2013) yang menyimpulkan bahwa komitmen organisasi berpengaruh positif dan signifikan terhadap kinerja karyawan.

$\mathrm{H}_{3}$ : Komitmen organisasi berpengaruh positif pada kinerja penyusun laporan keuangan satuan kerja wilayah pembayaran KPPN Denpasar.

Fadli et al. (2012) menyatakan bahwa karyawan yang sudah mempunyai kompetensi yang baik, maka perusahaan akan mempertahankan karyawan untuk tetap bekerja dengan memberikan gaji, tunjangan, dan lain-lain yang sesuai dengan kompetensinya, dengan timbal balik antara perusahaan dengan karyawan, maka karyawan akan berkomitmen terhadap perusahaan tempat bekerja. Sujana (2012) menyatakan bahwa kompetensi berpengaruh secara signifikan dan positif terhadap komitmen organisasi, artinya semakin tinggi kompetensi auditor internal/pegawai inspektorat, maka semakin tinggi pula komitmennya terhadap organisasi. Sebaliknya semakin rendah kompetensi auditor internal/pegawai inspektorat, maka semakin rendah komitmennya terhadap organisasi.

$\mathrm{H}_{4}$ : Kompetensi berpengaruh positif pada komitmen organisasi penyusun laporan keuangan satuan kerja wilayah pembayaran KPPN Denpasar.

Robbins (2006:283) menyatakan budaya organisasi dapat dijadikan alat untuk mempertinggi komitmen organisasi dan meningkatkan eksistensi perilaku 
karyawan. Lok dan Crawford (2004) menyatakan bahwa budaya organisasi berpengaruh positif pada kepuasan kerja dan komitmen organisasi, budaya organisasi sebagai hasil kesepakatan bersama akan menjadikan anggota organisasi tersebut mempunyai rasa tanggungjawab dalam mengimplementasikan aspekaspek penting budaya organisasi tersebut. Hal ini akan mendorong timbulnya itikad baik atau komitmen anggota terhadap organisasi yang menaunginya, hal tersebut selaras dengan Momeni et al. (2012) dan Hakim (2015).

$\mathrm{H}_{5}$ : Budaya organisasi berpengaruh positif pada komitmen organisasi penyusun laporan keuangan satuan kerja wilayah pembayaran KPPN Denpasar.

Patulak et al. (2013) menunjukkan bahwa bagaimanapun kompetensi yang tinggi dari karyawan yang ditunjukkan oleh indikator pengetahuan, keterampilan dan sikap tidak dapat secara langsung mempengaruhi peningkatan kinerja, namun dengan dimediasi komitmen organisasi tinggi yang ditandai dengan kelanjutan indikator, di mana karyawan merasa memiliki tanggung jawab yang tinggi untuk tetap dalam organisasi dan merasa kehilangan jika mereka tidak melakukan tugas sebagai tanggung jawab mereka, memiliki dampak yang signifikan dalam meningkatkan kinerja karyawan

$\mathrm{H}_{6}$ : Komitmen organisasi memediasi pengaruh kompetensi pada kinerja penyusun laporan keuangan satuan kerja wilayah pembayaran KPPN Denpasar.

Robbins (2006:283) menyatakan budaya organisasi yang kuat memiliki dampak terhadap sikap karyawan. Semakin banyak anggota organisasi yang menerima nilai-nilai inti dan semakin besar komitmen karyawan terhadap nilainilai tersebut, maka akan semakin kuat suatu budaya. Patulak et al. (2013) menyimpulkan bahwa terdapat pengaruh positif dan signifikan budaya organisasi 
pada kinerja karyawan yang dimediasi oleh komitmen organisasi. Budaya organisasi merupakan bagian dari kelangsungan organisasi yang terbentuk dari sikap dan perilaku anggota organisasi, budaya dapat membentuk komitmen anggotanya. Anggota organisasi yang memiliki komitmen yang kuat akan bekerja dengan dedikasi sehingga menghasilkan kinerja yang baik.

$\mathrm{H}_{7}$ : Komitmen organisasi memediasi budaya organisasi pada kinerja penyusun laporan keuangan satuan kerja wilayah pembayaran KPPN Denpasar.

\section{METODE PENELITIAN}

Penelitian ini mengambil lokasi di Kantor Pelayanan Perbendaharaan Negara (KPPN) Denpasar. Populasi dalam penelitian ini adalah penyusun laporan keuangan pada satuan kerja di wilayah pembayaran KPPN Denpasar. Metode pengambilan sampel dilakukan dengan menggunakan teknik purposive sampling, yaitu teknik pengambilan sampel berdasarkan kriteria tertentu atau dengan pertimbangan (judgement) tertentu (Sugiyono, 2013:122). Responden dalam penelitian ini adalah pegawai yang bekerja pada satuan kerja dengan kode kewenangan Kantor Daerah (KD) dan telah mengikuti program percepatan akuntabilitas keuangan pemerintah implementasi akuntansi berbasis akrual dan Sistem Akuntansi Instansi Berbasis Akrual (SAIBA), sehingga didapatkan sampel yang memenuhi kriteria berjumlah 144 orang.

Variabel dalam penelitian ini terdiri atas variabel dependen (terikat) yaitu kinerja penyusun laporan keuangan satuan kerja, variabel independen (bebas) yaitu kompetensi dan budaya organisasi dan variabel intervening yaitu komitmen organisasi. Uji instrumen penelitian (validitas dan reliabilitas) dilakukan sebelum 
kuesioner disebarkan pada responden. Uji asumsi klasik yang dilakukan sebelum melakukan pengujian hipotesis, diantaranya: uji normalitas, uji multikolinearitas dan uji linearitas.

Definisi operasional variabel penelitian sebagai berikut:

1) Kinerja Penyusun Laporan Keuangan $(\mathrm{KNJ})$

Persepsi kinerja sebagai penyusun laporan keuangan adalah adalah hasil kerja yang dihasilkan oleh penyusun laporan keuangan sesuai dengan perannya dalam organisasi, khususnya dalam rangka melaksanakan penyusunan laporan keuangan. Instrumen penelitian menggunakan instrumen yang dikembangkan Mitchel dan Larson (1987) dalam Wasasih (2015). Indikator yang dijadikan ukuran kinerja penyusun laporan keuangan, yaitu: kemampuan, prakarsa inisiatif, ketepatan waktu, petunjuk teknis dan ketelitian dan komunikasi.

2) Kompetensi (COMP)

Kompetensi adalah karakteristik yang mendasari seseorang berkaitan dengan efektivitas kinerja individu dalam pekerjaannya atau karakteristik dasar yang memiliki hubungan kasual. Pengukuran yang dilakukan adalah dengan melihat persepsi penyusun laporan keuangan terhadap kompetensi yang dimiliki. Instrumen penelitian menggunakan instrumen yang dikembangkan (Herawati, 2015). Variabel kompetensi menggunakan tiga indikator yaitu : keterampilan, pengetahuan dan sikap.

3) Budaya Organisasi (CULTUR)

Budaya organisasi adalah nilai-nilai dan keyakinan yang dianut oleh anggota suatu organisasi dalam bentuk norma-norma perilaku para individu atau 
kelompok organisasi tersebut. Indikator budaya organisasi diukur dengan 7 indikator yang dikembangkan oleh (Robbins, 2006). Variabel budaya organisasi menggunakan 7 indikator yaitu: Inovasi dan mengambil risiko, perhatian pada hal yang rinci, orientasi hasil, orientasi manusia, orientasi tim, agresifitas dan stabilitas.

4) Komitmen Organisasi (COMIT)

Komitmen organisasi ialah sebuah keadaan psikologi yang berkarakteristik hubungan karyawan dengan organisasi yang mempengaruhi loyalitas karyawan terhadap organisasinya. Instrumen penelitian menggunakan instrumen yang dikembangkan Rismawan (2014). Tiga indikator yang digunakan untuk mengukur komitmen organisasional (Mowday et al., 1979 dalam Luthans, 2006), yaitu: komitmen afektif, komitmen kontinyu dan komitmen normatif.

Pengujian hipotesis menggunakan teknik Analisis Jalur (Path Analysis) yang merupakan bagian dari analisis regresi. Koefisien jalur pengaruh langsung antar variabel ditunjukkan oleh nilai Standardized coefficients dan untuk menguji kekuatan pengaruh tidak langsung dilakukan dengan Uji Sobel. Persamaan regresi yang dapat dibentuk adalah:

$\mathbf{K N J}=b_{1} \mathrm{COMP}+b_{2} \mathbf{C U L T}+b_{3}$ COMIT $+\mathbf{e} \ldots \ldots \ldots \ldots \ldots \ldots$ (1)

COMIT $=b_{4} \mathrm{COMP}+b_{5} \mathbf{C U L T}+\mathbf{e} \ldots \ldots \ldots \ldots \ldots \ldots \ldots \ldots . . . \ldots \ldots(2)$

Keterangan:

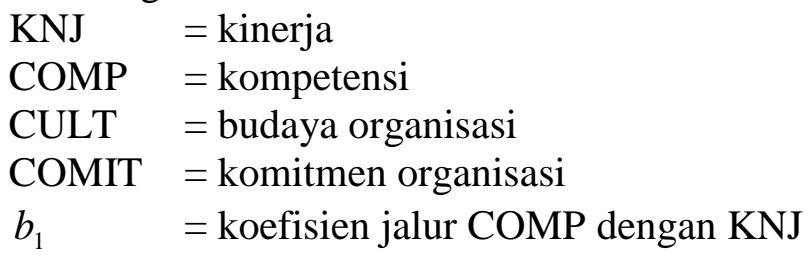




$$
\begin{array}{ll}
b_{2} & =\text { koefisien jalur CULT dengan KNJ } \\
b_{3} & =\text { koefisien jalur COMIT dengan KNJ } \\
b_{4} & =\text { koefisien jalur COMP dengan COMIT } \\
b_{5} & =\text { koefisien jalur CULT dengan COMIT } \\
\mathrm{e} & =\text { error }
\end{array}
$$

\section{HASIL DAN PEMBAHASAN}

Uji validitas dan reliabilitas instrumen penelitian dilakukan pada 30 orang penyusun laporan keuangan pada satuan kerja di direktorat jenderal kebudayaan. Berdasarkan hasil uji validitas variabel kompetensi, budaya organisasi, komitmen organisasi dan kinerja diperoleh nilai koefisien korelasi bernilai positif serta lebih besar dari 0,361 dan signifikansi lebih kecil dari alpha 0,05, sehingga dapat dinyatakan bahwa intrumen penelitian ini valid. Hasil uji reliabilitas nilai Alpha Cronbach untuk variabel kompetensi, budaya organisasi, komitmen organisasi dan kinerja berturut-turut adalah sebesar 0,951, 0,967, 0,808 dan 0,970 sehingga dapat dinyatakan bahwa intrumen penelitian ini reliabel.

Setelah kuesioner penelitian dinyatakan valid dan reliabel, selanjutnya dilakukan penyebaran kuesioner. Sebanyak 261 kuesioner yang disebar merupakan jumlah responden yang memenuhi kriteria 1 yaitu pegawai yang bekerja di satuan kerja dengan kode kewenangan Kantor Daerah (KD) dengan pengembalian kuesioner sebanyak 247 kuesioner atau berjumlah 94,63\% dan kuesioner yang tidak kembali sebanyak 14 kuesioner atau 5,36\%. Kuesioner yang memenuhi kriteria 2 yaitu pegawai yang telah mengikuti program percepatan akuntabilitas keuangan pemerintah implementasi akuntansi berbasis akrual dan Sistem Akuntansi Instansi Berbasis Akrual (SAIBA) sebanyak 158 kuesioner. 
Dari kuesioner tersebut 14 kuesioner tidak lengkap dalam pengisiannya sehingga dikeluarkan dari sampel. Jadi total sampel yang memenuhi kriteria 1 dan kriteria 2 serta pengisiannya lengkap berjumlah 144 kuesioner. Kuesioner yang tidak digunakan sebanyak 103 kuesioner terdiri dari 89 kuesioner tidak memenuhi kriteria 2 dan 14 kuesioner tidak lengkap dalam pengisiannya.

Mayoritas responden berusia 31 - 40 tahun yaitu berjumlah 63 orang atau $43,75 \%$, sisanya $<26$ tahun berjumlah 6 orang atau 4,17\%, 26-30 tahun berjumlah 39 orang atau $27,08 \%, 41-50$ tahun berjumlah 31 orang atau 21,53\% dan $>51$ tahun berjumlah 5 orang atau 3,47\%. Responden yang berpendidikan SMA berjumlah 26 orang atau 18,06\%, D3 berjumlah 28 orang atau 19,44\%, Sarjana (S1) berjumlah 80 orang atau 55,56\%, Magister (S2) berjumlah 8 orang atau $5,56 \%$ dan D1 berjumlah 2 orang atau 1,39\%.

Lama bekerja responden digunakan untuk mengetahui tingkat pengalaman kerja responden yang berpartisipasi dalam proses penyusunan laporan keuangan di satuan kerja. Responden yang bekerja $<2$ tahun berjumlah 31 orang atau 21, 53\%. 2- 5 tahun berjumlah 53 orang atau 36,81\%,> 5 tahun berjumlah 60 orang atai $41,67 \%$. Jenis kelamin responden digunakan untuk mengetahui besarnya keterlibatan gender dari penyusunan laporan keuangan. Responden yang berjenis kelamin laki-laki berjumlah 86 orang atau 59,72\%, sedangkan responden yang berjenis perempuan berjumlah 58 orang atau $40,28 \%$.

Hasil uji asumsi klasik yang diolah dengan menggunakan SPSS 21 menunjukkan bahwa variabel dalam penelitian berdistribusi normal, bebas dari multikoleniaritas dan linear. Uji normalitas yang dilakukan dengan menggunakan 
uji Kolmogorov-Smirnov menunjukkkan signifikansi tiap variabel sebesar 0,770 pada persamaan 1 dan 1,050 pada persamaan 2. Pada dua model persamaan regresi mempunyai nilai lebih besar dari 0,05. Jadi dapat disimpulkan bahwa model persamaan regresi telah memenuhi asumsi normalitas data. Variabel dalam penelitian ini juga bebas dari multikoleniaritas, ditunjukkan dengan nilai VIF tiap variabel tidak ada yang melebihi 10 dan nilai tolerance tidak ada yang kurang dari 10\% seperti ditunjukkan pada Tabel 1 berikut:

\section{Tabel 1}

\section{Hasil Uji Multikolinearitas}

\begin{tabular}{lllll}
\hline Variabel & Persamaan 1 & \multicolumn{3}{c}{ Persamaan 2 } \\
& Tolerance & VIF & Tolerance & VIF \\
\hline Kompetensi & 0.315 & 3.179 & 0.331 & 3.022 \\
Budaya Organisasi & 0.327 & 3.058 & 0.331 & 3.022 \\
Komitmen Organisasi & 0.760 & 1.315 & & \\
\hline
\end{tabular}

Sumber: Data diolah, 2016

Uji linieritas pada curve fit menunjukkan bahwa seluruh model dalam penelitian ini signifikan yang berarti bahwa model berbentuk linier sehingga model tersebut layak untuk diterapkan. Hasil uji linearitas ditunjukkan pada Tabel 2 berikut :

Tabel 2

Ringkasan Model Linear

\begin{tabular}{llllll}
\hline Hubungan Variabel & $\boldsymbol{R}^{2}$ & df1 & df2 & P value & Keterangan \\
\hline COMP $\rightarrow$ KNJ & 0,997 & 2 & 142 & .000 & signifikan \\
CULT $\rightarrow$ KNJ & 0,997 & 2 & 142 & .000 & signifikan \\
COMIT $\rightarrow$ KNJ & 0,994 & 2 & 142 & .000 & signifikan \\
COMP $\rightarrow$ KNJ & 0,992 & 2 & 142 & .000 & signifikan \\
CULT $\rightarrow$ KNJ & 0,991 & 2 & 142 & .000 & signifikan \\
\hline Sumber
\end{tabular}

Sumber : Data diolah, 2016 
Hasil uji regresi pengaruh kompetensi, budaya organisasi dan komitmen organisasi terhadap kinerja penyusun laporan keuangan dapat dilihat pada Tabel 3 di bawah ini:

\section{Tabel 3}

Pengaruh kompetensi, budaya organisasi dan komitmen organisasi terhadap kinerja penyusun laporan keuangan satuan kerja

\begin{tabular}{|c|c|c|c|c|c|}
\hline \multirow{3}{*}{ Model } & \multicolumn{2}{|c|}{ Unstandardized Coefficients } & \multirow{3}{*}{$\begin{array}{c}\text { Standardized } \\
\text { Coefficients } \\
\text { Beta } \\
\end{array}$} & \multirow{3}{*}{$\mathrm{t}$} & \multirow{3}{*}{ Sig. } \\
\hline & & & & & \\
\hline & B & Std. Error & & & \\
\hline (Constant) & 21,419 & 4,102 & & 5,221 & 0,000 \\
\hline COMP & 0,503 & 0,167 & 0,278 & 3,009 & 0,003 \\
\hline CULT & 0,503 & 0,095 & 0,478 & 5,267 & 0,000 \\
\hline COMIT & 0,195 & 0,096 & 0,122 & 2,045 & 0,043 \\
\hline
\end{tabular}

Sumber: Data diolah, 2016

Hasil regresi pengaruh kompetensi dan budaya organisasi pada komitmen organisasi penyusun laporan keuangan dapat dilihat pada Tabel 4 di bawah ini:

\section{Tabel 4}

Pengaruh kompetensi dan budaya organisasi pada komitmen organisasi penyusun laporan keuangan satuan kerja

\begin{tabular}{|c|c|c|c|c|c|}
\hline \multirow{2}{*}{ Model } & \multicolumn{2}{|c|}{ Unstandardized Coefficients } & \multirow{2}{*}{$\begin{array}{c}\text { Standardized } \\
\text { Coefficients } \\
\text { Beta } \\
\end{array}$} & \multirow{2}{*}{$\mathrm{t}$} & \multirow{2}{*}{ Sig. } \\
\hline & $\mathrm{B}$ & Std. Error & & & \\
\hline (Constant) & 19,139 & 3,234 & & 5,918 & 0,000 \\
\hline COMP & 0,388 & 0,144 & 0,345 & 2,702 & 0,008 \\
\hline CULT & 0,108 & 0,084 & 0,166 & 1,297 & 0,197 \\
\hline
\end{tabular}

Sumber: Data diolah, 2016

Hasil statistik dan konsep penelitian ditunjukkan dalam ringkasan koefisien jalur berikut: 


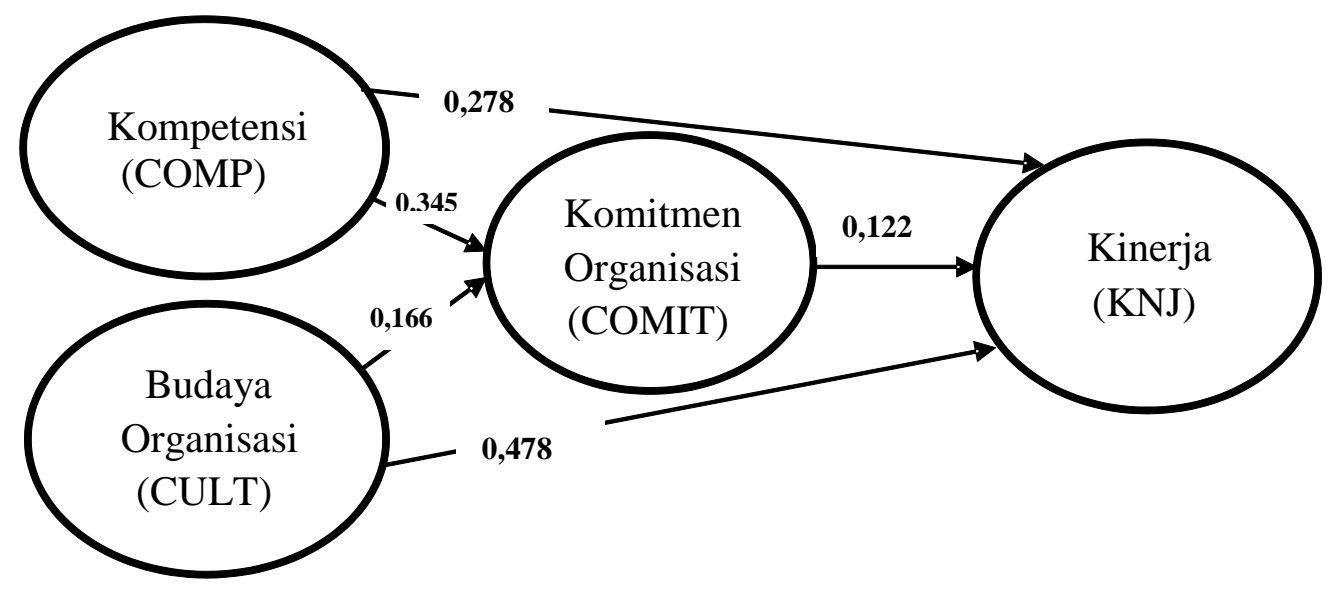

Gambar 1.

Koefisien Jalur Hubungan Antar Variabel

Indikator validitas model yang terdapat dalam path analysis, adalah koefisien determinasi total $\left(R^{2} m\right)$ yaitu sebesar 0,714. Berdasarkan hasil perhitungan koefisien determinasi total, maka dapat dinyatakan bahwa keragaman data yang didapat dijelaskan oleh model adalah sebesar 71,4 persen atau dengan kata lain informasi yang terkandung dalam data sebesar 71,4 persen dapat dijelaskan oleh model, sedangkan sisanya yaitu 28,6 persen dijelaskan oleh variabel lain (tidak terdapat dalam model) dan error.

Hasil Path Analysis menunjukkan, koefisien pengaruh kompetensi pada kinerja yaitu 0,278 dengan signifikansi 0,003 lebih kecil dari alpha 0,05. Hal ini berarti hipotesis pertama $\left(\mathrm{H}_{1}\right)$ yang menyatakan bahwa terdapat pengaruh positif kompetensi pada kinerja penyusun laporan keuangan satuan kerja wilayah pembayaran KPPN Denpasar, diterima. Koefisien budaya organisasi pada kinerja sebesar 0,478 dan nilai signifikansi 0,000 lebih kecil dari alpha 0,05. Hal ini berarti hipotesis kedua $\left(\mathrm{H}_{2}\right)$ yang menyatakan bahwa terdapat pengaruh positif budaya organisasi pada kinerja penyusun laporan keuangan satuan kerja wilayah 
pembayaran KPPN Denpasar, diterima. Koefisien pengaruh komitmen organisasi pada kinerja sebesar 0,122 dan nilai signifikansi 0,043 lebih kecil dari alpha 0,05. Hal ini berarti hipotesis ketiga $\left(\mathrm{H}_{3}\right)$ yang menyatakan bahwa terdapat pengaruh positif komitmen organisasi pada kinerja penyusun laporan keuangan satuan kerja wilayah pembayaran KPPN Denpasar, diterima. Dari ketiga hasil hipotesis, persamaan regresi yang dapat dibentuk adalah:

$\mathrm{KNJ}=0,278 \mathrm{COMP}+0,478 \mathrm{CULT}+0,122 \mathrm{COMIT}+\mathrm{e}$

Koefisien pengaruh kompetensi pada komitmen organisasi sebesar 0,345 dan nilai signifikansi 0,003 lebih kecil dari alpha 0,05. Hal ini berarti hipotesis keempat $\left(\mathrm{H}_{4}\right)$ yang menyatakan bahwa terdapat pengaruh positif kompetensi pada komitmen organisasi penyusun laporan keuangan satuan kerja wilayah pembayaran KPPN Denpasar, diterima. Koefisien pengaruh budaya organisasi pada komitmen organisasi sebesar 0,166 dan nilai signifikansi 0,197 lebih besar dari alpha 0,05 . Hal ini berarti hipotesis kelima $\left(\mathrm{H}_{5}\right)$ yang menyatakan bahwa terdapat pengaruh positif budaya organisasi pada komitmen organisasi penyusun laporan keuangan satuan kerja wilayah pembayaran KPPN Denpasar, ditolak. Dari kedua hasil hipotesis, persamaan regresi yang dapat dibentuk adalah:

$\mathrm{COMIT}=0,345 \mathrm{COMP}+\mathrm{e}$

Berdasarkan uji sobel, pengaruh kompetensi pada kinerja melalui komitmen organisasi menunjukkan nilai Zhitung sebesar 2,2407 yang lebih besar dari nilai Ztabel pada tingkat signifikansi 0,05 yaitu 1,645 . Koefisien pengaruh kompetensi pada kinerja melalui komitmen organisasi sebesar 0,320. Hal ini berarti hipotesis keenam (H6) yang menyatakan bahwa komitmen organisasi 
memediasi pengaruh kompetensi pada kinerja penyusun laporan keuangan satuan kerja wilayah pembayaran KPPN Denpasar, diterima. Hasil uji sobel pengaruh budaya organisasi pada kinerja melalui komitmen organisasi menunujukkan nilai Zhitung sebesar 2,4358 yang lebih besar dari nilai Ztabel pada tingkat signifikansi 0,05 yaitu 1,645. Sedangkan Koefisien pengaruh budaya organisasi pada kinerja melalui komitmen organisasi sebesar 0,498. Hal ini berarti hipotesis ketujuh $\left(\mathrm{H}_{7}\right)$ yang menyatakan bahwa komitmen organisasi memediasi pengaruh budaya organisasi pada kinerja penyusun laporan keuangan satuan kerja wilayah pembayaran KPPN Denpasar, diterima.

Hipotesis pertama $\left(\mathrm{H}_{1}\right)$ yang menyatakan bahwa kompetensi berpengaruh positif pada kinerja, hasil ini berarti semakin tinggi kompetensi maka akan meningkatkan kinerja seorang pegawai. Hal ini menguatkan pandangan Spencer (1993) yang memandang bahwa pengetahuan, ketrampilan dan perilaku sebagai karakteristik kompetensi memprediksi atau menyebabkan suatu kinerja efektif. Hasil yang pengujian ini bermakna, bahwa variabel pengetahuan (berpikir analitis, berpikir konseptual, dan pengetahuan tentang pekerjaan) merupakan satu kesatuan yang terintegrasi dan bersinergi mampu membentuk kinerja yang efektif. Hasil penelitian ini sejalan dengan penelitian yang dilakukan oleh Herawati (2015) yang menyatakan kompetensi berpengaruh pada kinerja karyawan. Hal ini diperkuat Wu (2008) yang menyatakan untuk meningkatkan kinerja maka perusahaan perlu meningkatkan kompetesi karyawannya.

Hipotesis kedua $\left(\mathrm{H}_{2}\right)$ yang menyatakan bahwa terdapat pengaruh positif budaya organisasi pada kinerja, hal ini berarti semakin kuat budaya organisasi 
yang diterapkan di instansi maka akan meningkatkan kinerja seorang pegawai. Pembentukan kinerja yang baik, dihasilkan jika terdapat komunikasi antara seluruh karyawan sehingga membentuk internalisasi budaya organisasi yang kuat dan dipahami sesuai dengan nilai-nilai organisasi yang dapat menimbulkan persepsi yang positif antara semua tingkatan karyawan untuk mendukung dan mempengaruhi iklim kepuasan yang berdampak pada kinerja karyawan. Penelitian ini mendukung penelitian Adi (2013) yang menguji pengaruh budaya organisasi pada kinerja kepala sekolah di Kabupaten Sukoharjo, dimana hasilnya menunjukkan bahwa budaya organisasi berpengaruh positif pada kinerja kepala sekolah. Hasil penelitian ini juga mendukung Gunaraja (2014) dan Haryanti (2014) yang menyatakan bahwa budaya organisasi mempunyai kontribusi positif terhadap kinerja karyawan.

Hipotesis ketiga $\left(\mathrm{H}_{3}\right)$ yang menyatakan bahwa terdapat pengaruh positif komitmen organisasi pada kinerja, hal ini berarti, semakin tinggi komitmen pegawai terhadap organisasinya maka akan meningkatkan kinerja. Hasil ini mendukung argumen yang disajikan dalam studi Allen dan Meyer (1990) mengemukakan bahwa pegawai yang memiliki continuance commitment yang tinggi tetap tinggal karena mereka merasa memerlukannya, seorang pegawai percaya bahwa akan terus bekerja dan bersedia mengerahkan banyak upaya atas nama organisasi dibandingkan dengan situasi di mana pekerjaan lebih atau kurang terjamin. Pegawai yang memiliki affective commitment yang tinggi akan tetap tinggal karena mereka menginginkannya, bersedia untuk mengerahkan upaya yang lebih besar atas nama organisasi. Pegawai yang memiliki normative 
commitment yang tinggi akan tetap tinggal karena mereka merasa seharusnya melakukannya demikian, mewajibkan pegawai untuk tetap di dalam organisasi dan berkomitmen untuk itu.

Hasil penelitian ini menunjukkan bahwa untuk meningkatkan kinerja pegawai, khususnya yang berkaitan dengan kemampuan, prakarsa inisiatif, ketepatan waktu, petunjuk teknis dan ketelitian serta komunikasi diperlukan dukungan dari komitmen karyawan yaitu (a) untuk tetap bekerja dalam organisasi karena mereka membutuhkan pekerjaan dan membutuhkan dukungan dari organisasi, baik secara finansial dan non-finansial demi kelangsungan hidup, (b) tetap dan berkontribusi upaya dan ide-ide dalam organisasi karena mereka merasa kewajiban moral untuk memberikan organisasi mencapai kesuksesan, dan (c) tetap bekerja dalam organisasi karena adanya keinginan dan kemauan dan ketulusan.

Hakim (2015) menyatakan bahwa komitmen organisasi memiliki pengaruh positif yang signifikan terhadap kinerja karyawan. Hal ini diperkuat oleh Tolentino (2013), Memari et al. (2013), Naveed et al. (2014) dan Rizal et al. (2014) yang menyatakan bahwa, komitmen organisasi memiliki kontribusi positif dan signifikan dalam meningkatkan kinerja.

Hipotesis keempat $\left(\mathrm{H}_{4}\right)$ yang menyatakan bahwa terdapat pengaruh positif kompetensi pada komitmen organisasi, hal ini berarti semakin tinggi kompetensi yang dimiliki pegawai maka akan meningkatkan komitmennya terhadap organisasi. Pemahaman yang baik akan fungsi dan kompetensi yang memadai dari seorang pegawai akan menumbuhkan komitmen tinggi terhadap organisasi. 
Dengan adanya ketiga indikator kompetensi yaitu keterampilan, pengetahuan dan sikap yang baik akan tugas dan fungsi sebagai seorang pegawai negeri yang bertugas menyusun laporan keuangan dengan baik dan berdasarkan peraturan yang berlaku, maka akan menumbuhkan idealisme terhadap tugas dan tanggungjawab, yang akhirnya akan bermuara pada munculnya komitmen diri untuk membantu organisasi melaksanakan pekerjaannya dengan baik.

Hasil penelitian ini sejalan dengan penelitian fadli et al. (2012) yang menguji pengaruh kompetensi karyawan PT. PLN Rengasdengklok pada komitmen organisasinya dimana hasilnya menunjukkan bahwa kompetensi berpengaruh positif terhadap komitmen organisasi. Hal tersebut diperkuat dengan Sujana (2012) yang menyatakan semakin tinggi kompetensi maka semakin tinggi komitmennya terhadap organisasi.

Hipotesis kelima $\left(\mathrm{H}_{5}\right)$ yang menyatakan bahwa tidak terdapat pengaruh budaya organisasi pada komitmen organisasi. Hal ini mengindikasikan bahwa budaya organisasi yang diterapkan di masing-masing instansi tidak menyebabkan peningkatan komitmen penyusun laporan keuangan terhadap organisasinya.

Hasil ini menunjukkan indikator budaya organisasi yaitu inisiatif dan berpikir kreatif pegawai dalam melaksanakan pekerjaan serta keberanian pegawai dalam mengambil resiko atas apa yang dikerjakan terbatas karena pegawai tidak dapat melaksanakan sesuai dengan keinginanannya melainkan harus sesuai dengan peraturan yang berlaku di instansi pemerintahan. Ada aturan yang membatasi pegawai melaksanakan kegiatan atau program-program pemerintah. 
Indikator agresif dan kompetitif dari pegawai kurang yang berarti bahwa penyelesaian pekerjaan hanya sebatas pada apa yang diberikan berdasarkan job description dari atasan, tantangan terhadap tugas-tugas yang baru kurang mendapat tanggapan dari pegawai. Semangat pegawai untuk berkompetisi dalam melakukan dan meraih prestasi tidak tampak dari para pegawai, hal ini dikarenakan pemberian penghargaan bagi yang berprestasi tidak diterapkan pada instansi pemerintahan. Oleh karena itu dibutuhkan motivasi dari pimpinan maupun dari instansi sehingga kepedulian dan rasa memiliki pegawai terhadap organisasinya akan meningkat. Penelitian ini menyimpulkan budaya organisasi tidak berpengaruh pada komitmen penyusun laporan keuangan terhadap organisasinya, sejalan dengan Logahan dan Aesaria (2012) dan Haryanti dan Cholil (2014).

Hipotesis keenam $\left(\mathrm{H}_{6}\right)$ yang menyatakan bahwa komitmen organisasi memediasi pengaruh kompetensi pada kinerja penyusun laporan keuangan, hal ini berarti komitmen organisasi sangat diperlukan oleh satuan kerja karena mampu menaikkan pengaruh kompetensi pada kinerja. Kompetensi disamping secara langsung dapat mempengaruhi kinerja, juga dapat menumbuhkan komitmen organisasi yang tinggi dalam diri penyusun laporan keuangan sehingga dengan adanya komitmen tersebut, maka akan berimplikasi pula pada kecenderungan peningkatan kinerja dari penyusun laporan keuangan. Sehingga satuan kerja instansi pemerintah hatus menumbuhkan dan meningkatkan komitmennya terhadap organisasi. 
Hasil penelitian ini konsisten dengan Haryanti dan Cholil (2014) menunjukkan bahwa bagaimanapun kompetensi yang tinggi dari karyawan yang ditunjukkan oleh indikator pengetahuan, keterampilan dan sikap secara langsung mempengaruhi peningkatan kinerja, namun dengan dimediasi komitmen organisasi tinggi yang ditandai dengan kelanjutan indikator, di mana karyawan merasa memiliki tanggung jawab yang tinggi untuk tetap dalam organisasi dan merasa kehilangan jika mereka tidak melakukan tugas sebagai tanggung jawab mereka, memiliki dampak yang signifikan dalam meningkatkan kinerja karyawan.

Hasil ini diperkuat oleh Patulak et al. (2013) dan Rumasukun et al. (2015) yang menyatakan bahwa komitmen organisasi merupakan variabel mediasi pengaruh kompetensi pegawai terhadap kinerja karyawan, terdapat pengaruh tidak langsung dari kompetensi pegawai terhadap kinerja pegawai melalui komitmen organisasi.

Hipotesis ketujuh $\left(\mathrm{H}_{7}\right)$ yang menyatakan bahwa komitmen organisasi memediasi pengaruh budaya organisasi pada kinerja penyusun laporan keuangan, hal ini berarti komitmen organisasi sangat diperlukan oleh satuan kerja karena mampu menaikkan pengaruh budaya organisasi pada kinerja. Budaya organisasi yang kuat, disamping secara langsung dapat mempengaruhi kinerja, juga dapat menumbuhkan komitmen organisasi yang tinggi dalam diri penyusun laporan keuangan sehingga dengan adanya komitmen tersebut, maka akan berimplikasi pula pada peningkatan kinerja dari penyusun laporan keuangan.

Hasil penelitian ini konsisten dengan Patulak et al. (2013) menyimpulkan bahwa terdapat pengaruh positif dan signifikan antara budaya organisasi terhadap 
kinerja karyawan yang dimediasi oleh komitmen organisasi. Budaya organisasi merupakan bagian dari kelangsungan organisasi yang terbentuk dari sikap dan perilaku anggota organisasi, budaya dapat membentuk komitmen anggotanya. Anggota organisasi yang memiliki komitmen yang kuat akan bekerja dengan dedikasi sehingga menghasilkan kinerja yang baik. Hal tersebut diperkuat Adi (2013) dan Hakim (2015) yang menyatakan terdapat pengaruh positif dan signifikan antara budaya organisasi terhadap kinerja karyawan yang dimediasi oleh komitmen organisasi.

\section{SIMPULAN DAN SARAN}

Berdasarkan penjelasan hasil analisis dan pembahasan sebelumnya dari variabel kompetensi, budaya organisasi dan komitmen organisasi pada kinerja penyusun laporan keuangan satuan kerja di wilayah pembayaran KPPN Denpasar, maka ada beberapa hal yang dapat disimpulkan. Pertama, terdapat pengaruh positif kompetensi pada kinerja. Hasil ini berarti semakin tinggi kompetensi maka kinerja penyusun laporan keuangan, cenderung semakin meningkat. Kedua, terdapat pengaruh positif budaya organisasi pada kinerja penyusun laporan keuangan. Hasil ini berarti semakin kuat budaya organisasi di satuan kerja maka kinerja penyusun laporan keuangan cenderung semakin meningkat. Ketiga, terdapat pengaruh positif komitmen organisasi pada kinerja penyusun laporan keuangan. Hasil ini berarti semakin tinggi komitmen organisasi penyusun laporan keuangan maka kinerjanya cenderung semakin meningkat. Keempat, terdapat pengaruh positif kompetensi pada komitmen organisasi penyusun laporan 
keuangan. Hasil ini berarti semakin tinggi kompetensi yang dimiliki penyusun laporan keuangan maka komitmennya terhadap organisasi, cenderung semakin meningkat. Kelima, tidak terdapat pengaruh budaya organisasi pada komitmen organisasi penyusun laporan keuangan. Hasil ini berarti budaya organisasi di instansi tidak mempengaruhi komitmen penyusun laporan keuangan satuan kerja terhadap organisasi. Keenam, terdapat pengaruh positif kompetensi pada kinerja penyusun laporan keuangan melalui komitmen organisasi. Hasil ini berarti semakin tinggi kompetensi maka semakin tinggi timbulnya komitmen penyusun laporan keuangan terhadap organisasi yang berdampak pada kecenderungan meningkatnya kinerja penyusun laporan keuangan satuan kerja wilayah pembayaran KPPN Denpasar. Ketujuh, terdapat pengaruh positif budaya organisasi pada kinerja penyusun laporan keuangan melalui komitmen organisasi. Hasil ini berarti semakin kuat budaya organisasi maka semakin tinggi timbulnya komitmen penyusun laporan keuangan terhadap organisasi yang berdampak pada kecenderungan meningkatnya kinerja penyusun laporan keuangan satuan kerja wilayah pembayaran KPPN Denpasar.

Berdasarkan simpulan dan keterbatasan dalam penelitian ini, maka penulis merekomendasikan beberapa saran. Pertama, Kompetensi, budaya organisasi dan komitmen organisasi merupakan hal penting yang perlu ditingkatkan dari pemerintah, khususnya satuan kerja di wilayah pembayaran KPPN Denpasar dalam meningkatkan kinerja penyusun laporan keuangan. Kedua, Adanya inkonsistensi hasil penelitian untuk variabel budaya organisasi pada komitmen organisasi, sehingga penelitian selanjutnya dapat meneliti kembali variabel 
tersebut menggunakan instrumen pengukuran yang berbeda. Ketiga, Satuan kerja dan pegawai diharapkan dapat meningkatkan budaya inovasi, berpikir kreatif, keberanian mengambil resiko serta agresifitas dalam bekerja sehingga budaya organisasi menjadi kuat yang berdampak pada meningkatnya komitmen pegawai terhadap organisasinya. Keempat, Penelitian selanjutnya diharapkan dapat menggali variabel-variabel yang berpotensi menumbuhkan atau memperkuat komitmen organisasi serta kinerja seperti kepemimpinan, motivasi dan kepuasan kerja. Disamping itu, dapat memperluas wilayah penelitian di daerah lain dan tidak hanya pada sektor publik tetapi juga pada sektor privat.

\section{REFERENSI}

Adi, B. Wasito. 2013. Analisis Pengaruh Budaya Organisasi, Kepemimpinan dan Motivasi Kerja terhadap Komitmen Organisasi dan Imlikasinya pada Kinerja kepala sekolah. Jurnal Pendidikan dan Kebudayaan, 19 (2): 206-221.

Adiputri, N.W.A. 2014. Hubungan Kompetensi, Kompensasi Finansial dan Supervisi dengan Kinerja Bidan Desa (Kabupaten Bangli) (tesis). Denpasar: Universitas Udayana.

Allen, Natalie J and Meyer, John P. 1990. The Measurement and Antecedents of Affective, Continuance and Normative Commitment to Organization. Journal of Occupational Psychology, 63: 1-18.

Anggraheni, D.I. 2010. Analisis atas Pelaporan Keuangan dan Pengungkapan Laporan Keuangan Unit Akuntansi Kuasa Pengguna Anggaran dan Unit Akuntansi Pembantu Pengguna Anggaran Wilayah (Studi Kasus Balai Besar Konservasi Sumber Daya Alam Jawa Barat). (tesis). Jakarta: Universitas Indonesia.

Anonim, 2010. Upaya Peningkatan kinerja seksi verak KPPN Tebingtinggi. http://kppntanjungbalai.files.wordpress.com. 07 Januari 2016. (20.00).

Badan Pemeriksa Keuangan Republik Indonesia. 2015. Laporan Hasil Pemeriksaan atas LKPP Tahun 2015. www.bpk.go.id. 03 Juni 2016. (21.00). 
Cohen, Aaron. 1999. Relationship Among Five Form of Commitment: An Empirical Assessment. Journal of Organizational Behavior, 20: 285-308. Available from: http://poli.haifa.ac.il.

Fadli, U.M., Fadili, D.A., Kartawijaya, Y. 2012. Pengaruh Kompetensi Karyawan terhadap Komitmen Kerja (PT. PLN Rayon Rengasdengklok). Jurnal Manajemen, 09 (20): 577-589.

Ghozali, Imam. 2016. Aplikasi Multivariate Dengan Program SPSS. Semarang. Badan Penerbit Universitas Diponegoro.

Gunaraja, TM. 2014. Organizational Culture on Employee Performance. IOSR Journal of Business and Management (IOSR-JBM). 16 (2): 38-42.

Hakim, A. 2015. Effect of Organizational Culture, Organizational Commitment to Performance: Study In Hospital Of District South Konawe Of Southeast Sulawesi. The International Journal Of Engineering And Science (IJES), 4: 3341.

Haryanti, S. dan Cholil. M. 2014. Pengaruh Gaya Kepemimpinan, Budaya Organisasi, Kompetensi Karyawan terhadap Kinerja dengan Komitmen Organisasi sebagai Variabel Mediasi. Jurnal Bisnis\&Manajemen, 15: 33-44. Universitas Sebelas Maret: Surakarta.

Herawati, N.L.M. 2015. "Pengaruh Pengawasan Pimpinan, Disiplin dan Kompetensi Pegawai Pada Kinerja Pegawai Inspektorat Kabupaten Tabanan" (tesis). Denpasar: Universitas Udayana.

Hofstede, G., Bram, N., Denise, D.O. and Geert, S. 1990. Measuring Organizational Culture: A Qualitative and Quantitative Study across Twenty Cases. Administrative Science Quarterly, 35: 286-316.

Hustanarina, F dan Nor, W. 2007. Pengaruh Keterlibatan Pekerjaan dan Budget Imphasis dalam Hubungan antara Partisipasi Anggaran dengan Senjangan Anggaran. The $1^{\text {st }}$ Accounting Conference Faculty of Economic Universitas Indonesia. 1-25.

Kementerian Keuangan. 2016. Surat Dirjen Perbendaharaan No. S-4841/PB/2016 tentang Pelaksanaan Rekonsiliasi Eksternal tingkat KPPN. http://www.djpbn.kemenkeu.go.id/. diakses 15 juni 2016.

Locke, E.A. 1968. Toward A Theory of Task Motivation and Incentives. American Institutes of Research, 16 (3): 157-89. 
Logahan, J.M dan Aesaria, S.M. 2014. Budaya Organisasi dan Keterlibatan Kerja terhadap Komitmen Organisasi Berdampak pada Kinerja Karyawan pada BTNCiputat. Binus Business review, 5(2): 551-563.

Lok, Peter dan Crawford, John. 2004. The Effect of Organizational Culture and Leadership Style on Job Satisfaction and Organizational Commitment. The Journal of Management Development, 23: 321-337.

Luthans, Fred. 2006. Perilaku Organisasi, Edisi kesepuluh. Terjemahan. Yogyakarta: Andi.

Memari, N., Mahdieh, O., Marnani, A.B. 2013. The Impact of Organizational Commitment Employees on Job Performance. A Study of Meli Bank. Interdiscipline Journal of Contemporary Research in Business, 5 (5): 164-171. Available from: Ijcrb.webs.com

Mimba, N.P.S.H. 2013. Penerapan Akuntansi Pemerintahan Berbasis Akrual Tinjauan Perspektif Manajemen SumberDaya Manusia. Modul Akuntansi Pemerintah Berbasis Akrual. BPKP. pp.65-72.

Modway, R., R. Steers, dan L. Porter, 1979. The Measurement of Organizational Commitment. Journal of Vacational Behavior, 14: 224-235.

Momeni, Mandan., Marjani, A.B dan Vajihed Saadat. 2012. The Relationship between Organizational Culture and Organizational Commitment in Staff Department of General Prosecutors of Tehran. International Journal of Business and Social Research, 3 (13): 217-221. Available from: www.ijbssnet.com.

Naveed Ahmad, Nadee Iqbal, Komal Naqvi Javel and Hamad. 2014. Impact of Organizational Commitment and Employee Performance on the Employee Satisfaction. Internatiional Journal of Learning, Teaching and Educational Research, 1 (1): 84-92.

Patulak, M.E., Thoyib, A., Surachman., Setiawan, M. 2013. The Role of Organizational Commitment as Mediator of Organizational Culture and Employees Competencies on Employees Performances: A Study on Irrigation Area Management in Southeast Sulawesi. Journal of Economics and Sustainable Development, 4 (5): 166-175.

Peraturan Menteri Keuangan Republik Indonesia Nomor 177/PMK.05/2015 tentang Pedoman Penyusunan dan Penyampaian Laporan Keuangan Kementerian Negara/Lembaga. 02 Januari 2016. (19.00). 
Rismawan, P.A.E. 2014. Peran Mediasi Komitmen Organisasi pada Pengaruh Stress Kerja dan Kepuasan Kerja terhadap Intensi Keluar Karyawan. (tesis). Denpasar: Universitas Udayana.

Rizal, M., Idrus, M.S., Djumahir., Mintarti, R. 2014. Effect of Compensation on Motivation, Organizational Commitment and Employee Performance (Studies at Local Revenue Management in Kendari City). International Journal of Business and Management Invention, 3 : 64-79.

Robins P. Stephen. 2006. Perilaku Organisasi. Edisi, kesepuluh. Terjemahan Benyamin Molan. Jakarta: PT Indeks Kelompok Gramedia.

Robbins, S.P dan Judge T. A. 2008. Perilaku Organisasi Organizational Behavior Edisi 12. Jakarta: Salemba Empat.

Rumasukun, S.F.A., Rante, Y., Wambrauw, O.O., Bharanti, B.E., 2015. The Influence of Human Resource Management Strategy and Competence on Employee Performance with the Mediation of Work Motivation, Organizational Commitment and Work Culture (Study at the Official of Management of Communication and Information Technology of Papua Province). International Journal of Business and Management Invention, 4 : $15-27$.

Samad, Saminah. 2011. The Effects of job Satisfaction on Organizational Commitment and Job Perfomance Relationship: A Case of Mangers in Malaysia's Manufacturing Companies. European Journal of Social Science, 18 (4).

Spencer, Lyle M. and Spencer, Signe M. 1993. Competence Work: Model for Superior Performance. John Wiley and Sons, Inc.

Sugiyono. 2012. Metode Penelitian Bisnis (Pendekatan Kuantitatif, Kualitatif dan $R \& D)$. Bandung: Penerbit Alfabeta.

Sujana, Edy. 2012. Pengaruh Kompetensi, Motivasi, Kesesuaian Peran dan Komitmen Organisasi terhadap Kinerja Auditor Internal Inspektorat Pemerintah Kabupaten (Studi Pada Kantor Inspektorat Kabupaten Badung dan Buleleng). Jurnal Ilmiah Akuntansi dan Humanika, 2 (1): 1-27.

Tolentino. R.C. 2013. Organizational Commitment and Job Performance of the Academic and Administrative Personnel. International Journal of Information Technology and Business Management, 15 (1): 51-59.

Uddin, Mohammad, J., Luva, Rumana H., Saad Md. Maroof Hossian. 2013. Impact of Organizational Culture on Employee Performance and Productivity: 
Veriyanto Adi Prakoso, Ni Made Dwi Ratnadi dan IGAM Asri Dwija P. Pengaruh Kompetensi...

A Case Study of Telecommunication Sector in Bangladesh. International Journal of Business and Management, 8 (2).

$\mathrm{Wu}$, Wei-Wen. 2008. Exploring core competencies For R\&D Technical Professionals. Expert System with Applications, 36 (5): 954-95. 